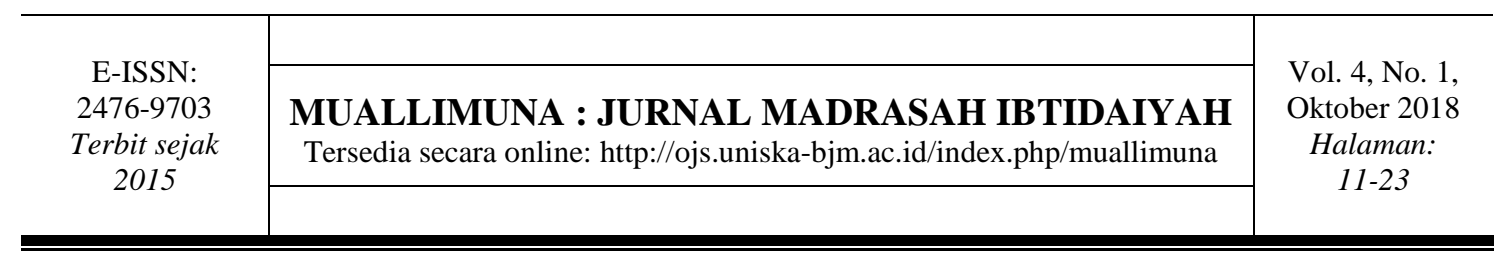

\title{
IMPLEMENTASI MODEL EXPERIENTIAL LEARNING UNTUK MENINGKATKAN KETERAMPILAN MENULIS KARANGAN NARASI SISWA SEKOLAH DASAR
}

\author{
Yeni Jayanti' ${ }^{1}$, Vina Anggia Nastitie Ariawan ${ }^{2}$ \\ SDN 02 Pesanggrahan', Pendidikan Guru Sekolah Dasar STKIP Majenang ${ }^{2}$ \\ 1yenijayanti69@gmail.com, ${ }^{2}$ vivianatsir@gmail.com
}

\begin{abstract}
Abstrak: Menumbuhkan kesenangan menulis terhadap siswa dapat dilakukan dengan memberikan pembelajaran yang sesuai dengan karakteristiknya. Siswa sekolah dasar pada umumnya senang dengan pembelajaran yang melibatkan dirinya. Pembelajaran yang melibatkan siswa akan membentuk pengalaman bagi siswa itu sendiri. Namun, kenyataan di lapangan masih banyak siswa sekolah dasar memiliki keterampilan menulis yang rendah khususnya menulis karangan narasi. Oleh sebab itu, penelitian ini bertujuan untuk meningkatkan keterampilan menulis karangan narasi siswa sekolah dasar melalui implementasi model experiential learning. Penelitian tindakan kelas kolaboratif terpilih sebagai metode penelitian dengan siswa kelas IV sebagai subjeknya. Penelitian ini berlokasi di salah satu sekolah dasar Desa Selang Kecamatan Kebumen. Peneliti mengumpulkan data melalui observasi, wawancara, dan tes. Sementara itu, analisis tematik digunakan sebagai teknik analisis data penelitian sedangkan triangulasi merupakan teknik untuk memvaliditas data. Hasil penelitian menunjukkan bahwa model experiential learning dapat meningkatkan keterampilan menulis karangan narasi siswa sekolah dasar.
\end{abstract}

Kata Kunci: experiential learning; keterampilan menulis; narasi; siswa sekolah dasar

\section{IMPLEMENTING EXPERIENTIAL LEARNING MODEL TO IMPROVE NARRATIVE WRITING SKILL OF ELEMENTARY SCHOOL STUDENTS}

\begin{abstract}
Developing writing interest to the students can be done by providing learning that is appropriate to their characteristics. Generally, elementary school students are enjoying the learning which involves themselves. Learning that involves students will build their experiences. However, the reality in the field there are still many elementary school students who have low writing skill especially on narrative writng skill. Consequently, this research aims to improve narrative writing skill of elementary school students by implementing experiential learning model. Collaborative action research was selected as research method within fourth grade students as its subjects. This research located at one of elementary school in Selang Village, Kebumen Sub-District. This research collected data by observation, interview, and test. On the other hand, thematic analysis is used as technique of analysis data meanwhile triangulation employed as technique of validating data. Research outcome shows experiential learning model can enhance narrative writing skill of elementary school students.
\end{abstract}

Keywords: experiential learning; writing skill; narrative; elementary school students 


\section{PENDAHULUAN}

Narasi adalah karangan yang menceritakan tentang peristiwa berdasarkan fiktif atau nonfiktif. Narasi dapat berupa pengalaman pribadi, informasi, cerita imajinasi, atau biografi yang tersusun secara kronologis (Stephen \& Muriel, 2013). Siswa sekolah dasar memperoleh pembelajaran menulis karangan sederhana di kelas tiga. Kemudian, pembelajaran menulis karangan narasi diperoleh siswa di kelas empat. Menulis karangan narasi bertujuan untuk meningkatkan keterampilan siswa dalam penyampaian ide, gagasan, dan pengembangan kosakata sehingga keterampilan menulis siswa semakin terasah (Williams \& Larkin, 2013). Oleh sebab itu, pembelajaran menulis perlu mendapat perhatian yang serius agar siswa percaya diri untuk menuangkan gagasan.

Namun, keterampilan menulis disinyalir menjadi salah satu keterampilan berbahasa yang paling sulit dikuasai oleh siswa. Asumsi tersebut diperkuat berdasarkan hasil survei tiga tahunan oleh PISA pada tahun 2014 yang diedarkan OECD bahwa keterampilan menulis siswa Indonesia masih berada di posisi yang rendah yakni menduduki peringkat 62 dari 72. Rendahnya keterampilan menulis siswa berkaitan erat dengan melemahnya tradisi menulis di Indonesia seiring pesatnya perkembangan teknologi (Budiani, 2018). Sejalan dengan riset yang dilakukan oleh PISA, hasil observasi peneliti terhadap keterampilan menulis siswa di salah satu sekolah dasar Desa Selang, Kecamatan Kebumen juga menunjukkan hal yang serupa. Nilai hasil ulangan Bahasa Indonesia tentang menulis karangan narasi hanya 52,63\% atau 10 siswa dari 19 siswa yang dapat mencapai nilai KKM Bahasa Indonesia sebesar 70. Masih ada 3 siswa yang memperoleh nilai 50 dan 6 siswa memperoleh nilai 60 sedangkan nilai tertinggi yang diraih siswa hanya 85. Selanjutnya, hasil wawancara menerangkan bahwa siswa lebih mengalami kesulitan dalam membuat karangan narasi dibandingkan dengan jenis karangan lainnya. Siswa masih sulit membayangkan apa yang akan mereka tulis, serta siswa belum mampu membuat karangan narasi dengan runtut. Hasil tulisan siswa masih terdapat banyak pengulangan kata dan belum bervariasi.

Ketika siswa menulis karangan narasi, ia harus menulis cerita secara nyata yang pernah dialami maupun cerita berdasarkan imajinasi. Hal ini menjadikan menulis karangan narasi lebih sulit dilakukan karena siswa harus mengembangkan imajinasi agar dapat menciptakan cerita yang logis dan bermakna. Pemilihan tema menulis sangat berpengaruh terhadap daya tarik menulis siswa. Ketidaksesuaian tema menulis dengan karakteristik siswa akan berdampak pada keterbatasan ide siswa saat menulis (Kolb, Longest, \& Jensen, 2013). Siswa akan menulis dengan baik jika tema yang digunakan berdasarkan pengalaman pribadinya. Oleh sebab itu, jika guru akan memberikan tema baru dalam menulis, hendaknya guru terlebih dahulu menciptakan pengalaman tersebut agar siswa mendapat gambaran tentang tema baru tersebut.

Salah satu model pembelajaran yang mengutamakan pengalaman dan keterlibatan siswa yaitu experiential learning. Model experiential learning merupakan model pembelajaran berdasarkan teori Kolb. Teori ini menerangkan bahwa lingkungan belajar perlu menyediakan kesempatan siswa untuk mengembangkan dan membangun pengetahuan melalui pengalamannya (Kolb, 2014). Pengalaman akan menyajikan dasar untuk melakukan refleksi dan observasi, mengkonseptualisasi, dan menganalisis pengetahuan dalam pikiran siswa (Yardley, Teunissen, \& Dornan, 2012). Experiential learning memberikan alternatif di dalam pembelajaran dan menyediakan pemahaman nyata tentang cara memperoleh kebermaknaan siswa dalam belajar. Experiential learning berpusat pada satu tujuan yang bermakna bagi siswa, kontinyu dengan kehidupan siswa, dan menjadikan siswa berinteraksi dengan lingkungan (Kolb, 2014). 
Mastini, Suwardi, \& Sumarwati (2016) melaksanakan penelitian tindakan kelas pada siswa sekolah menengah di Surakarta. Penelitian Mastini, Suwardi, \& Sumarwati bertujuan untuk meningkatkan keterampilan menulis cerpen melalui model experiential learning. Hasil tes menulis cerpen selama dua siklus mengalami peningkatan dari 65,62\% menjadi 84,38\%. Hasil observasi dan wawancara menunjukkan bahwa keaktifan, perhatian, dan motivasi siswa semakin meningkat. Siswa bersemangat menjawab pertanyaan guru dan antusias menulis cerpen. Selain itu, proses pembelajaran melalui experiential learning memicu interaksi antara guru dengan siswa maupun antarsiswa. Penelitian Mastini, Suwardi, \& Sumarwati membuktikan bahwa model experiential learning dapat meningkatkan keterampilan menulis cerpen siswa SMP.

Berdasarkan penelitian sebelumnya, maka peneliti menyimpulkan bahwa model experiential learning terbukti dapat meningkatkan keterampilan menulis siswa di jenjang SMP. Experiential learning memberikan pembelajaran yang bermakna bagi siswa sehingga tidak mudah terlupakan. Menurut Cahyani (2012:164) model Experiential learning merupakan model pembelajaran yang dapat memberikan keaktifan kepada siswa untuk membangun pengetahuan, keterampilan, dan sikap melalui pengalaman yang mereka dapatkan dari dunia nyata. Sejalan dengan pendapat tersebut, Griffith, et al. (2016); Sriani, Sutama, \& Darmayanti (2015) berpendapat bahwa model pembelajaran experiential learning adalah suatu model pembelajaran yang memberikan pengetahuan dan keterampilan berdasarkan pengalaman melalui kegiatan observasi dan refleksi. Selanjutnya Canboy, et al. (2014) menjelaskan melalui model pembelajaran experiential learning siswa akan mengubah pengalaman yang telah didapatkannya menjadi sebuah pengetahuan. Pengalaman akan menjadikan dasar bagi siswa untuk melakukan observasi, refleksi, dan menganalisis pengetahun yang ada dalam pikiran siswa.Pengalaman tersebut dapat menjadi ide menulis sehingga siswa tidak ragu untuk menulis suatu karangan narasi. Penerapan model pembelajaran memiliki langkah-langkah yang harus dilaksanakan guna mendukung tercapainya tujuan pembelajaran yang hendak dicapai. Merujuk pada pemaparan sebelumnya, maka peneliti berupaya untuk meningkatkan keterampilan menulis karangan narasi siswa sekolah dasar melalui implementasi model experiential learning.

\section{METODE}

Penelitian ini menggunakan metode penelitian kualitatif dengan desain penelitian tindakan kelas model Kemmis \& Mc Taggart. Penelitian tindakan kelas merupakan bentuk refleksivitas untuk mengatasi permasalahan pembelajaran di kelas melalui suatu tindakan yang dilakukan secara individual maupun kolaboratif (Cohen, Manion, \& Marison, 2011). Desain penelitian tindakan kelas model Kemmis \& Mc Taggart dikenal dengan sistem spiral reflektif yang terdiri dari tahap perencanaan, tindakan, observasi, dan refleksi. Penelitian tindakan kelas adalah upaya yang dilakukan untuk memperbaiki keadaan atau memecahkan masalah yang dihadapi dalam kegiatan pembelajaran (Mulyasa, 2013: 34). Arikunto, Suhardjono, \& Supardi (2013: 63) menjelaskan salah satu ciri khas PTK yaitu adanya kolaborasi atau kerja sama antara praktisi dan peneliti.Penelitian dilaksanakan oleh mahasiswa sebagai peneliti dibantu teman sejawat selaku observer, dan guru kelas IV sebagai praktisi. Partisipan penelitian ialah 19 siswa kelas IV di salah satu sekolah dasar Desa Selang, kecamatan Kebumen.

Adapun teknik pengumpulan data menggunakan observasi, wawancara, dan tes. Teknik observasi yaitu suatu pengumpulan data dengan mengadakan pengamatan langsung terhadap suatu objek penelitian. Melalui observasi, peneliti langsung turun ke lapangan untuk mengamati perilaku dan aktivitas individu-individu di lokasi penelitian (Creswell, 2013). 
Observasi adalah cara pengumpulan data dengan mengadakan pencatatan terhadap hal yang menjadi sasaran pengamatan. Observasi sebagai alat pengumpul data dimanfaatkan untuk mengamati keterlaksanaan model experiential learning dalam pembelajaran menulis karangan narasi.

Selanjutnya, wawancara adalah kegiatan tanya jawab yang dilakukan untuk mendapatkan informasi secara lebih mendalam terkait sikap sains serta pembelajaran inkuiri. Dalam penelitian kualitatif, wawancara terjadi ketika peneliti menanyakan berbagai pertanyaan yang bersifat terbuka (Creswell, 2015). Wawancara terdiri dari wawancara terstruktur dan wawancara tidak terstruktur. Peneliti menggunakan wawancara terstruktur untuk mengumpulkan data penelitian. Wawancara terstruktur adalah wawancara yang telah dipersiapkan secara matang serta pertanyaan-pertanyaan yang akan diajukan telah dipersiapkan terlebih dahulu (Azwar, 2013).

Tes digunakan untuk mengukur hasil belajar siswa setelah kegiatan pembelajaran. Sanjaya (2013: 99) menjelaskan bahwa tes merupakan instrumen pengumpulan data untuk mengukur kemampuan kognitif atau tingkat penguasaan materi pembelajaran siswa. Penelitian ini menggunakan jenis tes tertulis membuat karangan narasi dengan tema tertentu yang diberikan kepada siswa. Tes dilakukan untuk mengukur keterampilan siswa dalam menulis karangan narasi. Tes dilaksanakan pada akhir pembelajaran sesudah penerapan model experiential learning di setiap pertemuan pada setiap siklusnya.

Analisis data dalam penelitian ini menggunakan teknik thematic analysis atau analisis tematik. Naughton \& Hughes (2009) menyatakan bahwa analisis tematik merupakan teknik analisis data yang dilakukan dengan cara melihat dan menemukan tema-tema dan kategori yang diperoleh dalam data yang telah dikodekan terlebih dahulu. Tahapan analisis data dalam penelitian ini yaitu (1) menyiapkan data mentah; (2) melakukan pengodean (coding); (3) klasifikasi kode; (4) penafsiran data; (5) penyajian data (Creswell, 2013). Validitas merupakan derajad ketepatan antara data yang terjadi pada obyek penelitian dengan data yang dilaporkan oleh peneliti. Creswell (2017: 269) mengungkapkan validitas dikatakan akurat apabila sesuai dengan sudut pandang peneliti, partisipan, atau pembaca. Data yang valid dapat diperoleh melalui teknik triangulasi. Sugiyono (2015: 273) menerangkan bahwa triangulasi merupakan teknik pengumpulan data dengan menggabungkan berbagai teknik pengumpulan data dan sumber data yang telah ada. Triangulasi yang digunakan dalam penelitian ini yaitu triangulasi sumber dan triangulasi teknik. Peneliti menggunakan triangulasi sumber untuk memperoleh data tentang penerapan model experiential learning yang bersumber dari guru dan siswa. Sementara itu, triangulasi teknik diperoleh melalui teknik observasi, wawancara, dan tes. Keberhasilan suatu penelitian dapat diukur melalui ketercapaian indikator yang dijadikan sebagai acuan keberhasilan atau keefektifan penelitian. Implementasi model experiential learning untuk meningkatkan keterampilan menulis karangan narasi dikatakan berhasil apabila $85 \%$ nilai siswa di atas KKM yaitu 70.

\section{HASIL DAN PEMBAHASAN}

\section{Hasil}

Sebelum melaksanakan penelitian, terlebih dahulu peneliti melakukan tes pratindakan untuk mengukur keterampilan menulis karangan narasi siswa sekolah dasar. Hasil tes keterampilan menulis karangan narasi siswa pada pratindakan tertera dalam tabel 1. berikut ini. 
Tabel 1. Nilai Keterampilan Menulis Karangan Narasi Siswa pada Pratindakan

\begin{tabular}{|ccccc|}
\hline No. & Nilai (x) & $\begin{array}{c}\text { Frekuensi } \\
(\mathrm{f})\end{array}$ & $\begin{array}{c}\text { Persentase } \\
(\%)\end{array}$ & Keterangan \\
\hline 1 & 50 & 1 & 5,26 & Belum Tuntas \\
2 & 54 & 2 & 10,53 & Belum Tuntas \\
3 & 60 & 2 & 10,53 & Belum Tuntas \\
4 & 63 & 4 & 21,05 & Belum Tuntas \\
5 & 70 & 4 & 21,05 & Tuntas \\
6 & 75 & 3 & 15,79 & Tuntas \\
7 & 80 & 2 & 10,53 & Tuntas \\
8 & 85 & 1 & 5,26 & Tuntas \\
\hline Jumlah & & 19 & 100 & \\
Nilai rata-rata & & 67,37 & & \\
Nilai tertinggi & & 85 & & \\
Nilai terendah & 50 & & \\
Jumlah siswa tuntas & 10 & 52,63 & \\
Jumlah siswa belum tuntas & 9 & 47,37 & \\
\hline
\end{tabular}

Berdasarkan tabel 1, peneliti menyimpulkan bahwa keterampilan menulis karangan narasi siswa sekolah dasar belum maksimal, sehingga perlu diadakan suatu tindakan. Tindakan yang akan dilakukan yaitu dengan menerapkan model experiential learning. Implementasi model experiential learning diharapkan dapat meningkatkan keterampilan menulis karangan narasi siswa. Setelah melaksanakan pratindakan maka pada pertemuan berikutnya peneliti melaksanakan penelitian melalui implementasi model experiential learning sebagai upaya meningkatkan keterampilan menulis karangan narasi siswa sekolah dasar. Tindakan dilaksanakan sebanyak 3 siklus dengan masing-masing siklus terdiri dari 2 pertemuan. Dengan demikian, jumlah tindakan keseluruhan pada penelitian ini sebanyak enam pertemuan. Kemudian, siswa melaksanakan evaluasi keterampilan menulis karangan narasi pada setiap akhir pertemuan. Nilai keterampilan menulis karangan narasi siswa diperoleh dari rata-rata pencapaian tiga aspek penilaian keterampilan menulis karangan narasi pada saat siswa menulis karangan narasi, meliputi 1) ruang lingkup isi, 2) penggunaan bahasa, dan 3) penggunaan ejaan. Hasil evaluasi pada setiap pertemuan lantas dibandingkan dengan tujuan peneliti dapat mengukur keterampilan menulis karangan narasi siswa pada setiap pertemuan. Setelah peneliti mengukur evaluasi siswa, maka peneliti dapat menyimpulkan ketercapaian indikator keterampilan menulis karangan narasi yang telah ditetapkan. Berikut peneliti uraikan hasil evaluasi di setiap siklusnya melalui grafik pada gambar 1. di bawah ini.

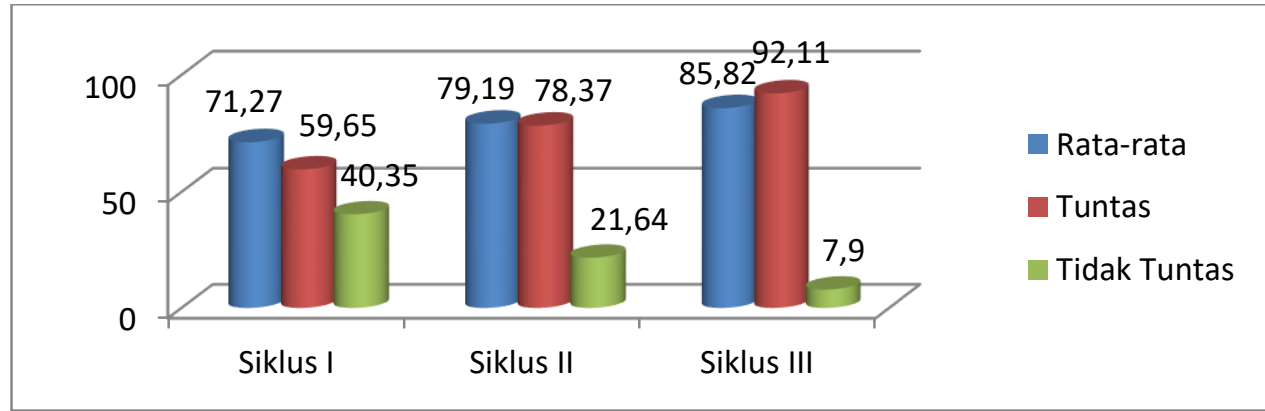

Gambar 1. Perbandingan Nilai Keterampilan Menulis Karangan Narasi Setiap Siklus

Implementasi model experiential learning untuk meningkatkan ... I Jayanti, Y., \& Ariawan, V.A.N. 
Pada aspek ruang lingkup isi, siklus I hasil karangan narasi siswa belum memuat unsur karangan berupa latar waktu dan latar tempat. Hasil karangan narasi siswa juga tersusun secara tidak runtut, karena susunan yang ditulis siswa masih terbolak-balik, seperti pengenalan, isi, pengenalan, lalu penutup. Selain itu, isi gagasan yang dikemukakan siswa masih ada yang belum sesuai dengan tema dan judul yang telah ditentukan. Pada siklus II dan III isi karangan narasi siswa sudah memuat unsur-unsur karangan yang lengkap, yaitu latar tempat, latar waktu, sudut pandang, dan alur. Hasil karangan narasi siswa sudah tersusun secara runtut dan sudah sesuai dengan judul dan tema yang telah ditentukan.

Pada aspek penggunaan bahasa, siklus I siswa masih banyak yang menggunakan kosakata bahasa daerah, pemilihan kosakata sederhana, dan karangan yang disusun siswa masih belum runtut. Selain itu, susunan pola kalimat yang ditulis kurang tepat, sehingga antarkalimat dalam paragraf kurang padu. Karangan siswa juga tersusun atas pengulangan kalimat di setiap paragrafnya, sehingga terkesan monoton. Pada siklus II pemilihan kata masih sederhana, namun kosakata bahasa daerah sudah mulai berkurang, dan karangan yang disusun siswa sudah mulai runtut serta mudah dipahami. Selain itu, susunan pola kalimat yang diguanakan sudah lebih baik dibandingkan siklus sebelumnya. Pada siklus III bahasa yang digunakana sudah efektif dan kompleks. Pemilihan kosakata sudah lebih variatif, walaupun masih terdapat beberapa kosakata bahasan daerah, dan pola kalimat yang digunakan sudah tepat. Kalimat-kalimat antar paragraf saling berkaitan dan mudah dipahami.

Pada aspek penggunaan ejaan, siklus I siswa belum memperhatikan penggunaan ejaan dalam menulis karangan narasi. Siswa sering sekali tidak menggunakan tanda titik (.) di akhir kalimat dan setelah tanda titik (.) tidak menggunakan huruf kapital. Siswa juga tidak menggunakan huruf kapital pada nama orang, nama tempat, maupun nama hari dan terdapat huruf kapital di tengah kata. Selain itu, pada awal paragraf tidak ditulis menjorok oleh siswa. Pada siklus II siswa menulis karangan narasi sudah mulai memperhatikan penggunaan ejaan. Pada awal kalimat sudah ditulis dengan menjorok, akhir kalimat sudah diberi tanda titik (.), dan setelah tanda (.) sudah menggunakan huruf kapital. Nama orang dan nama hari sudah ditulis dengan huruf kapital. Namun masih terdapat beberapa siswa yang menuliskan huruf kapital di tengah kata. Pada siklus III penggunaan ejaan sudah baik hanya terdapat sedikit kesalahan. Seluruh siswa sudah menulis awal paragraf dengan menjorok, dan siswa sudah memperhatikan penggunaan tanda titik (.) serta penggunaan huruf kapital. Selain itu, siswa juga menggunakan tanda koma (,) dan tanda petik (“...”).

Adapun kendala yang muncul dalam penelitian yaitu siswa kurang terlibat aktif dalam kegiatan bertukar cerita dan bertanya jawab. Ketika guru meminta siswa untuk bertukar cerita dengan teman sebangku serta bertanya jawab mengenai pengalaman yang telah dilakukan, ada beberapa siswa yang tidak terlibat aktif dalam kegiatan tersebut. Siswa hanya mengajukan pendapatnya apabila ditunjuk oleh guru. Beberapa siswa ada yang ramai sendiri dan bermain dengan teman sebangkunya seolah-olah tidak ada yang memperhatikan dirinya. Hal tersebut dapat diakibatkan karena kurangnya motivasi mengikuti pembelajaran dalam diri siswa, padahal motivasi dapat mempengaruhi keberhasilan pembelajaran seseorang.

Kendala selanjutnya yaitu hasil karangan narasi yang dibuat siswa ada yang hanya satu paragraf saja. Hal tersebut berbanding terbalik dengan jumlah kerangka karangan yang telah dibuat siswa. Kesulitan mengembangkan kerangka karangan yang dialami siswa dapat disebabkan karena rendahnya minat membaca. Siswa yang kurang gemar membaca akan mengalami kesulitan dalam menulis, walaupun berdasarkan pengalamannya sendiri. Tidak gemar membaca juga mengakibatkan jumlah kosakata yang dimiliki siswa sedikit, sehingga 
membuat mereka kesulitan dalam menulis. Kendala tersebut muncul pada siklus I pertemuan 1 dan 2.

\section{Pembahasan}

Peningkatan keterampilan menulis karangan narasi dapat ditinjau dari peningkatan nilai rata-rata hasil pencapaian tiga aspek menulis karangan narasi, yaitu a) ruang lingkup isi, b) penggunaan bahasa, dan c) penggunaan ejaan. Pada aspek ruang lingkup isi, guru membimbing siswa untuk mengembangkan karangan sesuai dengan kerangka karangan yang telah dibuat, sehingga isi karangan yang diungkapkan siswa terarah dan tidak keluar dari sasaran. Hal tersebut juga bertujuan agar hasil karangan yang dibuat siswa memiliki keterkaitan antarparagraf, sehingga mudah untuk dipahami. Langkah model experiential learning yang dapat meningkatkan nilai aspek ruang lingkup isi yaitu concrete experience (pengalaman nyata) dan reflection observation (observasi refleksi). Hal ini dikarenakan dalam langkah tersebut siswa mengalami secara langsung kegiatan yang berhubungan dengan tema menulis yang akan digunakan. Pada langkah reflection observation (observasi refleksi) siswa saling berdiskusi dengan teman sebangkunya mengenai pengalaman yang telah dilakukan. Hasil diskusi siswa, kemudian dijadika sebagai acuan dalam membuat kerangka karangan. Hal ini sesuai dengan pendapat Kolb, et al (2014) bahwa melalui kegiatan secara langsung dan merefleksi kegiatan tersebut akan mempermudah siswa dalam menulis, karena ide yang akan digunakan siswa bersumber dari dirinya sendiri.

Menyusun kerangka karangan sangat penting dilakukan, karena kerangka karangan dijadikan sebagai kalimat utama dalam setiap paragraf dari karangan narasi yang akan disusun. Selain itu, kerangka karangan memudahkan siswa dalam mengarang, karena melalui kerangka karangan tersebut tulisan yang akan dibuat siswa sudah memiliki tujuan atau arah yang sesuai dengan tema yang telah ditentukan. Seperti fungsi kerangka yang diungkapkan Suhartono (2011: 71) yaitu untuk memberikan fokus/arah supaya tidak keluar dari sasaran. Pada aspek penggunaan bahasa, guru membimbing dan memberikan contoh kepada siswa untuk menggunakan taha bahasa yang baik, sehingga dapat menghasilkan kalimat yang efektif. Hal ini bertujuan agar tulisan yang dihasilkan siswa tersusun secara runtut dan mudah untuk dipahami.

Langkah model experiential learning yang lebih dominan meningkatkan penggunaan bahasa adalah abstrak conceptualization (penyusunan konsep abstak). Hal ini dikarenakan dalam langkah ini siswa mendapatkan materi tentang penggunaan bahasa. Selain itu, guru juga membimbing dan mengingatkan siswa untuk menulis menggunakan bahasa yang baik serta baku. Guru membiasakan berbicara dengan menggunakan bahasa yang baku, dan sangat jarang menggunakan kosakata bahasa daerah. Hal tersebut bertujuan untuk melatih siswa dan membiasakan siswa supaya menggunakan bahasa Indonesia yang baku. Seperti yang diungkapkan Bing (2013) bahwa dengan melakukan suatu perbuatan yang berulang-ulang akan membekas dalam diri siswa, sehingga menjadi suatu kebiasaan yang sulit apaila harus ditinggalkan.

Penggunaan tata bahasa yang baik berfungsi agar siswa dapat menghasilkan kalimat yang efektif. Seperti pendapat Suhartono (2011: 27) bahwa kalimat efektif merupakan kalimat yang digunakan dengan tepat dalam ragam bahasa tertentu. Kalimat efektif akan lebih mudah dipahami, sehingga menjadikan karangan narasi lebih tersusun secara runtut dan tidak menghasilkan penafsiran makna yang berbeda. Pada aspek penggunaan ejaan, guru menjelaskan penggunaan ejaan yang benar dalam menulis karangan, sehingga siswa mampu menggunakan ejaan yang sesuai. Selain menjelaskan materi tentang penggunaan ejaan, guru juga menyuruh siswa untuk menganalisis karangan narasi. Analisis karangan narasi ini 
terdapat dalam langkah ketiga model experiential learning yaitu abstract conceptualization (penyusunan konsep abstrak). Dalam langkah ini siswa menganalisis penggunaan ejaan dalam contoh karangan narasi. Kegiatan ini dilakukan sebagai implikasi dari materi yang telah mereka dapatkan dari guru. Dengan melakukan analisis siswa akan menemukan sendiri penerapan penggunaan ejaan yang benar maupun kesalahan yang terjadi, serta siswa dapat memperbaikinya. Seperti yang diungkapkan Bing (2013) bahwa melalui praktik secara langsung yang dilakukan siswa akan mempermudah siswa dalam melakukan hal-hal yang pernah dipelajarinya. Penggunaan ejaan dalam suatu karangan memiliki kedudukan yang penting, yaitu untuk memperkecil terjadinya kesalahan makna. Hal tersebut sesuai dengan pendapat Suhartono (2011: 86) bahwa ejaan memiliki kedudukan yang penting dalam bahasa tulis, sehingga dapat memperkecil terjadinya kesalahan makna.

Hasil penelitian menunjukkan bahwa model experiential learning dapat meningkatkan keterampilan menulis karangan narasi siswa sekolah dasar. Keterampilan menulis siswa meningkat dari setiap aspeknya yang meliputi aspek isi, unsur bahasa, dan ejaan. Peneliti membiasakan siswa untuk menulis satu paragraf dalam setiap pertemuan. Pada pertemuan pertama dan kedua siswa masih terlihat enggan menulis. Hasil menulis siswa masih sangat rancu karena mereka kesulitan menulis pengalamannya. Pada pertemuan selanjutnya, siswa sudah mulai antusias untuk menulis pengalamannya. Hasil menulis siswa sudah membentuk suatu karangan dibanding pertemuan sebelumnya dan lebih variatif karena terdapat dialog. Peningkatan tersebut menunjukkan bahwa pengalaman merupakan salah satu komponen penting dalam menulis.

Pelaksanaan pembelajaran Bahasa Indonesia tentang menulis karangan narasi melalui implementasi model experiential learning yang dilaksanakan melalui empat langkah meliputi a) concrete experience (pengalaman nyata), b) reflection observation (observasi refleksi), c) abstract conceptualization (penyusunan konsep abstrak), dan d) active experimentation (eksperimen aktif). Experiential Learning Theory (ELT) merupakan teori yang dikembangkan oleh Kolb serta mendasari model pembelajaran experiential learning. Experiential learning menawarkan perbedaan yang mendasar dan melihat proses belajar didasarkan atas epistemologi empiris (Relles, 2016). Teori ini menekankan akan kebutuhan lingkungan belajar dengan menyediakan kesempatan siswa belajar untuk mengembangkan dan membangun pengetahuan melalui pengalamannya. Pengalaman akan menyajikan dasar untuk melakukan refleksi, observasi, mengkonseptualisasi, dan menganalisis pengetahuan dalam pikiran siswa (Canboy, et al., 2014).

Belajar dari pengalaman mencakup keterkaitan antara berbuat (doing) dan berpikir (thinking). Experiential learning dapat diartikan sebagai tindakan untuk mencapai sesuatu berdasarkan pengalaman secara terus menerus sehingga mengalami perubahan untuk meningkatkan keefektifan dari hasil belajar (Tomkins \& Eatough, 2013). Tujuan dari experiential learning yaitu a) mengubah struktur kognitif siswa, b) mengubah sikap siswa, c) memperluas keterampilan yang sudah dimiliki siswa (Djamarah \& Zain, 2013). Kualitas belajar experiential learning mencakup keterlibatan siswa secara personal, berinisiatif, dan evaluasi oleh siswa sendiri dan adanya efek atau kesan yang membekas pada siswa sehingga merujuk pada pemerolehan kebutuhan (Rosier, et al., 2016). Tujuan model experiential learning sejalan dengan teori pembelajaran kontruktivis sosial Vygotsky. Teori tersebut menjelaskan bahwa kontruksi pengetahuan fisik dan logika matematis bersifat interindividualistis. Proses kontruksi pengetahuan melalui pengalaman tidak dapat terjadi pada ruang lingkup yang kosong. Seseorang akan belajar lebih baik apabila terlibat secara aktif dalam proses belajar (Griffith, et al., 2016). 
Experiential learning mendefinisikan pembelajaran sebagai suatu proses yang diperoleh melalui kombinasi antara memperoleh pengalaman dengan mentransformasi pengalaman. Kegiatan mengkonstruksi pengalaman dapat terjadi secara langsung melalui indra atau tidak secara langsung yaitu berupa bentuk simbolis. Sementara itu, kegiatan mentransformasi pengalaman berupa refleksi dan bereksperimen (Dyke, 2017). Pengalaman memberi peranan penting dalam menumbuhkan pengetahuan. Kebermaknaan belajar tergantung cara manusia belajar. Apabila belajar hanya dengan membaca, kebermaknaan belajar dapat mencapai $10 \%$, dari mendengar mencapai $20 \%$, dari melihat sebanyak $30 \%$, mendengar dan melihat sebanyak 70\%, mengomunikasikan sebanyak $70 \%$, dan belajar dengan melakukan serta mengomunikasikan dapat mencapai 90\% (Silberman, 2014). Persentase tersebut menunjukkan bahwa kegiatan belajar dengan peran aktif siswa dalam pengalaman nyata dapat mengoptimalkan kegiatan dalam pencapaian tujuan belajar.

Pada langkah concrete experience (pengalaman nyata), guru menciptakan pengalaman belajar yang menyenangkan serta melibatkan siswa sebagai dasar untuk memberi ide dalam menulis. Dalam langkah ini, guru mengajak siswa untuk melakukan berbagai aktivitas dalam pembelajaran. Aktivitas yang dilakukan dalam penelitian ini berupa kegiatan bermain ular naga, bermain gobag sodor, membuat kaleng penerima suara, bermain pesan berantai, menyusun puzzle dan gambar seri, serta melakukan kegiatan petualangan. Aktivitas tersebut diharapkan dapat memberikan pengalaman baru, maupun membantu siswa mengingat pengalaman yang telah mereka miliki sebelumnya. Hal tersebut sesuai dengan pendapat Majid (2013: 78) bahwa aktivitas berangkat dari pengalaman formal maupun informal yang pernah dialami sebelumnya atau yang belum pernah dialami dalam situasi realistik.

Langkah kedua yaitu reflection observation (refleksi observasi), guru merefleksi dengan cara memberikan kesempatan kepada siswa untuk menceritakan pengalamannya. Dalam langkah ini, siswa menceritakan pengalaman yang telah dilakukan serta guru bertanya pada siswa mengenai pengalaman yang pernah dialami. Guru menjelaskan jika setiap kegiatan yang telah dilakukan merupakan suatu pengalaman. Pengalaman tidak hanya tentang liburan, tetapi kegiatan sehari-hari yang biasa dilakukan dapat pula dikatakan sebagai pengalaman. Melalui kegiatan ini siswa dapat menghubungkan antara pengetahuan yang telah mereka miliki dengan pengetahuan baru. Hal tersebut sesuai dengan pendapat Ginting (2013: 9) bahwa kegiatan refleksi dapat membantu siswa dalam membuat hubungan antara kegiatan yang telah dilakukan dengan pengalaman baru.

Langkah ketiga yaitu abstract conceptualization (penyusunan konsep abstrak), guru menyuruh siswa untuk membaca dan menganalisis contoh karangan narasi. Hal-hal yang perlu dianalisis yaitu unsur-unsur karangan, penggunaan ejaan, serta struktur kalimat. Kemudian guru dan siswa membahas hasil diskusi tentang unsur karangan dan koreksi ejaan serta struktur kalimat. Selanjutnya guru memberi informasi tentang aspek-aspek yang perlu diperhatikan siswa dalam karangan. Dalam proses ini siswa mulai mengkonseptualisasi suatu teori atau model dari pengalaman yang diperoleh dan mengintegrasikannya dengan pengalamanan sebelumnya (Manolis, Burns, \& Chinta, 2013: 89). Langkah keempat yaitu active experimentation (eksperimen aktif), yaitu siswa mengaplikasikan hasil kesimpulannya berdasarkan pengalaman pada situasi baru. Hal yang dilakukan siswa yaitu menentukan judul dan membuat kerangka karangan kemudian dikembangkan menjadi sebuah karangan yang utuh. Dalam langkah ini terjadi proses bermakna karena pengalaman yang telah diperoleh siswa sebelumnya diterapkan dalam situasi yang baru (Kolb, 2014: 154).

Model experiential learning memberi kesempatan pada siswa untuk melakukan aktivitas belajar secara aktif dan efektif. Model experiential learning memberi serangkaian kondisi dan situasi belajar dalam bentuk keterlibatan pengalaman langsung dan sesungguhnya 
yang dirancang guru (Humphrey, 2014). Model experiential learning mengarahkan siswa untuk mendapatkan pengalaman lebih banyak dan efektif melalui keterlibatan secara langsung dan personal. Model experiential learning sejalan dengan pandangan Dewey terkait makna pembelajaran. Menurut Dewey, pembelajaran merupakan proses melakukan, mereaksi, menemukan, dan mengalami. Siswa memperoleh hasil belajar berdasarkan aktivitas yang telah dilakukan (Bower, 2014). Selain itu, Dewey juga memaparkan bahwa pendidikan sejati berlangsung melalui pengalaman edukatif. Pengalaman yang telah dialami siswa mempunyai peranan penting dalam pembentukan pengetahuan kognitif dalam pikiran siswa.

Belajar berdasarkan pengalaman juga sesuai dengan konsep Ausubel terkait belajar bermakna. Menurut Ausubel belajar bermakna akan terjadi apabila informasi baru yang diterima siswa memiliki kaitan erat dengan konsep relevan yang sudah ada/diterima sebelumnya dan tersimpan dalam struktur kognitifnya. Ausubel menjelaskan bahwa pengalaman memberi siswa jalan untuk menemukan pemahaman bukan menerima pemahaman (Dahar, 2011). Oleh sebab itu, experiential learning berpengaruh terhadap keterampilan menulis siswa. Setiap pengalaman memberi kebermaknaan sehingga siswa dapat menulis gagasan terkait pengalamannya.

Dampak lain dari experiential learning yaitu siswa mengikuti pembelajaran dengan antusias dan gembira. Keantusiasan saat pembelajaran terjadi karena siswa memperoleh pengalaman belajar yang menyenangkan seperti bermain ular naga, gobag sodor, dan melakukan petualangan. Setiap pembelajaran ada kegiatan membaca sehingga dapat menambah kosakata siswa. Keterlibatan siswa dalam pembelajaran akan memberi pengalaman sehingga siswa dapat mengkonstruk pengetahuannya. Hal ini sejalan dengan experiential learning theory yang dikemukakan oleh Kolb bahwa pembelajaran merupakan proses untuk membangun pengetahuan melalui serangkaian pengalaman konkret maupun abstrak (Tomkins \& Ulus, 2016).

Pelaksanaan penelitian tidak terlepas dari adanya kendala. Kendala yang muncul selama penelitian yaitu kurangnya keterlibatan siswa dalam kegiatan bertukar cerita dan tanya jawab serta kurangnya keterampilan siswa dalam pengembangan paragraf dari kerangkan karangan. Melihat adanya kendala yang muncul maka peneliti menyarankan solusi pada guru selaku praktikkan. Adapun solusi yang dapat dilakukan untuk mengatasi kendala tersebut, yaitu guru memotivasi siswa agar terlibat aktif dalam kegiatan bertukar cerita dan tanya jawab. Upaya membangkitkan semangat siswa dalam melakukan kegiatan bertukar cerita dan tanya jawab mengenai pengalaman yang telah dilakukan, guru dapat melakukannya dengan memberikan memotivasi kepada siswa. Hal tersebut dilakukan supaya siswa antusias dalam menyampaikan pendapatnya tanpa harus ditunjuk, mengingat bahwa motivasi belajar memiliki pengaruh yang besar terhadap perilaku belajar siswa. Pendapat tersebut sejalan dengan pendapat yang disampaikan Widoyoko (2014: 233) bahwa motivasi belajar memiliki pengaruh terhadap perilaku belajar siswa, yaitu meningkatkan semangat siswa dalam belajar. Selanjutnya, guru memberikan latihan dan bimbingan khusus kepada siswa yang mengalami kesulitan dalam mengembangkan kerangka karangan menjadi karangan yang utuh. Bimbingan yang dilakukan guru dapat berupa petunjukpetunjuk agar siswa gemar membaca, sehingga kosakata yang dimiliki siswa dapat bertambah menjadi lebih banyak. Hal tersebut sesuai dengan pendapat Sabahiyah, Marhaeni, dan Suastra (2013) bahwa guru dapat membimbing siswa dengan cara memberikan petunjuk-petunjuk. Kemudian, guru juga memfasilitasi siswa dengan berbagai contoh karangan narasi yang ada dalam majalah, karangan yang dibuat guru sendiri, atau karangan yang ada di buku ajar. Aktivitas ini diharapkan membantu siswa untuk menemukan ide atau memberi gamabran pada siswa terkait pengembangan paragraf. 
Penelitian tentang model experiential learning juga telah dilakukan oleh McManus \& Thiamwong (2015). McManus \& Thiamwong melaksanakan penelitian tindakan kelas untuk meningkatkan keterampilan menulis siswa kelas IV sekolah dasar melalui penerapan model experiential learning. Hasil penelitian McManus \& Thiamwong menunjukkan bahwa penerapan model experiential learning dapat meningkatkan keterampilan menulis siswa kelas IV sekolah dasar. Peningkatan dibuktikan dari hasil menulis siswa yang hampir memenuhi aspek menulis yang meliputi aspek isi, organisasi, ejaan, dan kosakata. Selain itu, hasil wawancara dengan siswa menyatakan bahwa experiential learning memberi dampak positif. Siswa terbiasa untuk menulis segala kejadian yang terjadi dan tiada hari dilalui tanpa menulis. Mengacu pada hasil penelitian sebelumnya serta hasil penelitian ini, maka peneliti meyimpulkan bahwa model experiential learning dapat meningkatkan keterampilan menulis karangan narasi siswa sekolah dasar.

\section{PENUTUP}

Menulis merupakan suatu aktivitas yang tidak dapat dipisahkan dari diri siswa dalam kegiatan pembelajaran. Hal tersebut dikarenakan hampir seluruh kegiatan pembelajaran membutuhkan menulis untuk mencatat materi yang telah disampaikan guru. Menulis diartikan sebagai suatu keterampilan berbahasa yang digunakan untuk berkomunikasi secara tidak langsung, tidak bertatap muka secara langsung dengan orang lain melainkan melalui media tulisan. Penelitian ini bertujuan untuk meningkatkan keterampilan menulis karangan narasi melalui implementasi model experiential learning. Model experiential learning merupakan model pembelajaran yang dapat memberikan keaktifan kepada siswa untuk membangun pengetahuan, keterampilan, dan sikap berdasarkan pengalaman yang telah dialami melalui kegiatan observasi dan refleksi terhadap hal-hal yang ada disekitarnya secara nyata.Hasil penelitian menunjukkan model experiential learning dapat meningkatkan keterampilan menulis karangan narasi siswa sekolah dasar. Peningkatan menulis karangan narasi juga terjadi pada setiap aspek menulis siswa.

kendala dalam penerapan model experiential learning yaitu siswa tidak terlibat aktif dalam kegiatan bertukar cerita dan tanya jawab mengenai pengalaman yang telah dilakukan maupun yang telah dimiliki, serta karangan narasi yang ditulis siswa masih sangat pendek. Upaya untuk mengatasi kendala tersebut yaitu guru memotivasi siswa untuk terlibat aktif dalam kegiatan bertukar cerita maupun tanya jawab, serta guru melatih dan membimbing siswa yang mengalami kesulitan menulis karangan narasi supaya rajin membaca. Melalui hal tersebut diharapkan kosakata yang dimilki siswa semakin bertambah, sehingga siswa dapat mengembangkan kerangka karangan narasi dengan mudah. Selain itu, guru menyediakan contoh karangan narasi sehingga dapat menjadi sumber inspirasi siswa dalam pengembangan ide dalam karangannya.

\section{DAFTAR PUSTAKA}

Arikunto, S., Suhardjono., \& Supardi. (2008). Penelitian tindakan kelas. Jakarta: Bumi Aksara.

Azwar, S. (2013). Metode penelitian. Yogyakarta: Pustaka Pelajar.

Budiani, S.A. (2018). Peningkatan keterampilan menulis teks eksposisi dengan menggunakan metode brainwriting. PAEDAGOGIE, 13 (1), 37-42.

Bing, J.P.K. (2013). Enhancing writing skills through action adventure video games. Journal of Education and Practice, 4 (15), 36-42. 
Bower, G.G. (2014). Theory and practice: Utilizing Dewey's experiential learning theory to implement a 5k road race. Journal of Hospitality, Leisure, Sport \& Tourism Education, 15 (1), 61-67.

Cahyani, I. (2012). Pembelajaran menulis berbasis karakter dengan pendekatan experiential learning. Bandung: Program Studi Pendidikan Dasar SPS UPI.

Canboy, B., et al. (2014).'Module 9': a new course to help students develop interdisciplinary projects using the framework of experiential learning theory. Innovations in Education and Teaching International, 53 (4), 1-14.

Cohen, L., Manion, L., \& Marrison, K. (2011). Research in education sixth edition. Newyork: Routledge.

Creswell, J.W. (2013). Research design: Pendekatan kualitatif, kuantitatif, dan mixed. Yogyakarta: Pustaka Pelajar.

Creswell, J.W. (2015). Riset pendidikan perencanaan, pelaksanaan, dan evaluasi riset kualitatif dan kuantitatif edisi kelima. Yogyakarta: Pustaka Pelajar.

Cresswell, J.W. (2017). Research design pendekatan metode kualitatif, kuantitatif, dan campuran. Yogyakarta: Pustaka Pelajar.

Dahar, R.W. (2011). Teori-teori belajar dan pembelajaran. Jakarta: Penerbit Erlangga.

Djamarah, S.B. \& Zain, A. (2013). Strategi belajar mengajar. Jakarta: Rineka Cipta.

Dyke, M. (2017). Paradoxes of a long life learning: An exploration of Peter Jarvis's contribution to experiential learning theory. International Journal of Lifelong Education, 36 (1-2), 23-34.

Ginting, K. (2013). Penerapan model pembelajaran contextual teaching and learning untuk meningkatkan aktivitas dan hasil belajar IPS siswa kelas V SD Negeri 060885 Medan. Jurnal Tematik, 3 (12), 1-22.

Griffith, R.L., dkk. (2016). Guided mindfulness: A self regulatory approach to experiential learning of complex skills. Theoretical Issues in Ergonomics Science, $18(2), 147-166$.

Humphrey, K.R. (2014). Lessons learned from experiential group work learning. Social Work with Group, 37, 67-72.

Kolb, A.Y., et al. (2014). On becoming an experiential educator: The educator role profile. Simulation \& Gaming, 45 (2), 204-234.

Kolb, D. A. (2014). Experiential learning: Experience as the source of learning and development. Upper Saddle River, NJ: Pearson.

Kolb, K.H., Longest, K.C., \& Jensen, M.J. (2013). Assesing the writing process: Do writing intensive first year seminars change how students write? Teaching Sociology, 41 (1), 20-31.

Majid, A. (2013). Strategi pembelajaran. Bandung: Remaja Rosdakarya.

Manolis, C., Burns, D.J., \& Chinta R. (2013). Assessing experiential learning styles: A methodological reconstruction and validation of the Kolb learning style inventory. Learning and Individual Differences, 23 (1), 44-52

Mastini, Suwandi, S., \& Sumarwati. (2016). Peningkatan keterampilan menulis cerpen melalui metode pembelajaran berbasis pengalaman berbantuan media audiovisual pada sekolah menengah pertama. Jurnal S2 Pendidikan Bahasa Indonesia, 1 (1), 22-34.

McManus, M.S. \& Thiamwong, L. (2015). Enhancing fourth grade students' writing achievement through purposeful experiential learning: An action research study. Universal Journal of Educational Research, 3 (12), 997-1000. 
Mulyasa, E. (2013). Praktik penelitian tindakan kelas. Bandung: Remaja Rosdakarya.

Naughton, G.M \& Hughes, P. (2009). Doing action research in early childhood studies: A step by step guide. USA: Open University Press.

Relles, S., \& Tierney, W. G. (2013). Understanding the writing habits of tomorrow's students: Technology and college readiness. Journal of Higher Education, 84 (4), 477-505.

Rosier, J., et al. (2016). The benefits of embedding experiential learning in the education of planners. Planning Practice \& Research, 31 (5), 486-499.

Sabahiyah., Marhaeni, A.A.A.N., dan Suastra, W. (2013). Pengaruh model inkuiri terbimbing terhadap keterampilan proses sains dan penguasaan konsep IPA Siswa Kelas V Gugus 03 Wanasaba Lombok Timur. Jurnal Program Pascasarjana Universitas Pendidikan Ganesha Program Studi Pendidikan Dasar, 3, 1-8.

Sanjaya, W. (2013). Penelitian tindakan kelas. Jakarta: Kencana Prenada Media Group.

Silberman, M. (2014). Handbook experiential learning strategi pembelajaran dari dunia nyata. Bandung: Nusa Media.

Sriani, Sutama, \& Darmayanti. (2015). Penerapan model pembelajaran experiential learning untuk meningkatkan kemampuan menulis paragraf deskripsi pada siswa kelas VII B SMP Negeri 2 Tampaksiring. Jurnal Pendidikan Bahasa dan sastra Indonesia, 3 (1), 1-11.

Stephen, C.C. \& Muriel, L.Y. (2013). Narrative and performative acts in cultural education: The teaching of writing as critical communication. Inter-Asia Cultural Studies, 14 (2), 213-227.

Sugiyono. (2015). Metode penelitian kuantitatif kualitatif dan $R \& D$. Bandung: Alfabeta.

Suhartono. (2011). Bahasa Indonesia untuk mahasiswa. Salatiga: Widya Sari Press.

Tomkins, L. \& Eatough, V. (2013). The feel of experience: Phenomenological ideas for organizational research. Qualitative Research in Organizations and Management, 8 (3), 258-275.

Tomkins, L., \& Ulus, E. (2016). Oh was that “experiential learning”?! Spaces, synergies and surprises with Kolb's learning cycle. Management Learning, 47 (2), 158-178.

Widoyoko, E.P. (2014). Teknik penyusunan instrumen penelitian. Yogyakarta: Pustaka Pelajar.

Williams, G. J. \& Larkin, R. F. (2013). Narrative writing, reading and cognitive processes in middle childhood: What are the links? Learning and Individual Differences, 28, 142-150.

Yardley, S., Teunissen, P.W., \& Dornan, T. (2012). Experiential learning: Transforming theory into practice. Medical Teacher, 34 (2), 161-164. 